\title{
Rhodanobacter thiooxydans sp. nov., isolated from a biofilm on sulfur particles used in an autotrophic denitrification process
}

\author{
Chang Soo Lee, Kwang Kyu Kim, Zubair Aslam and Sung-Taik Lee \\ Department of Biological Sciences, Korea Advanced Institute of Science and Technology, \\ 373-1 Guseong, Yuseong, Daejeon, Republic of Korea
}

Correspondence

Sung-Taik Lee

e_stlee@kaist.ac.kr
At the time of writing, the genus Rhodanobacter accommodates three species: Rhodanobacter lindaniclasticus (Nalin et al., 1999), isolated from a soil sampled from a wood-treatment site and which degrades lindane $(\gamma$ hexachlorocyclohexane); Rhodanobacter fulvus (Im et al., 2004), isolated from soil mixed with rotten rice straw and which produces $\beta$-galactosidase; and Rhodanobacter spathiphylli (De Clercq et al., 2006), isolated from the rhizospheres of Spathiphyllum plants grown in a compostamended potting mix. Although the species were first isolated from widely separated geographical locations, all members of the genus Rhodanobacter have emerged from soil environments.

Various denitrification processes to remove nitrate from wastewater have been developed and studied. The autotrophic denitrification process can use sulfur particles as an energy source. This process is cheaper and easier to handle than the heterotrophic denitrification approach, involving organic chemicals (Batchelor \& Lawrence, 1978; Claus \& Kutzner, 1985; Koenig \& Liu, 1996; Zhang \& Lampe, 1999), but the exact microbial roles are not yet known.

During a study of the role of the bacterial communities that reside in the biofilms on sulfur particles used in an autotrophic denitrification process, a laboratory-scale upflow anaerobic sludge blanket reactor fed with such sulfur particles was used to enumerate and identify the bacteria involved. A biofilm from sulfur particles was

The GenBank/EMBL/DDBJ accession number for the 16S rRNA gene sequence of strain LCS2 $^{\top}$ is AB286179. thoroughly suspended in $50 \mathrm{mM}$ phosphate buffer (pH 7.0). The suspension was spread on one-tenthstrength R2A agar (Difco). The agar plates were incubated for 1 month at room temperature under both aerobic and anaerobic conditions, and each single colony was incubated once again using half-strength R2A agar. Consequently, seven strains were isolated under aerobic conditions. They were subjected to identification by means of conventional biochemical tests, analysis of the cellular fatty acids and partial 16S rRNA gene sequencing. Only one strain, $\mathrm{LCS} 2^{\mathrm{T}}$, was shown to represent a novel species.

The effect of thiosulfate on growth of strain $\mathrm{LCS}_{2}{ }^{\mathrm{T}}$ was tested in succinate/mineral medium containing $\left(1^{-1}\right) 0.4 \mathrm{~g}$ $\mathrm{NH}_{4} \mathrm{Cl}, 0.8 \mathrm{~g} \mathrm{~K} \mathrm{KPO}_{4}, \quad 0.3 \mathrm{~g} \quad \mathrm{KH}_{2} \mathrm{PO}_{4}, 2.7 \mathrm{~g}$ sodium succinate hexahydrate, $0.1 \mathrm{~g}$ yeast extract and $5 \mathrm{ml}$ mineral solution (Frankel et al., 1997). The $\mathrm{pH}$ was adjusted to 7.5 with $\mathrm{NaOH}$. The medium was supplemented with various amounts of thiosulfate, resulting in final concentrations ranging from 0 to $20 \mathrm{mM}$. Growth in liquid medium at $30{ }^{\circ} \mathrm{C}$ with vigorous shaking was investigated. Autotrophic growth was tested by omitting succinate from the succinate/mineral medium and replacing the yeast extract with $0.5 \mathrm{ml}$ vitamin solution $\mathrm{l}^{-1}$ (Frankel et al., 1997). The ability to grow anaerobically was determined by supplementing the R2A or succinate/mineral medium with $\mathrm{KNO}_{3}$ $\left(2 \mathrm{~g} \mathrm{l}^{-1}\right)$ or $\mathrm{Fe}_{4}\left(\mathrm{P}_{2} \mathrm{O}_{7}\right)_{3}\left(3.72 \mathrm{~g} \mathrm{l}^{-1}\right)$ as an alternative electron acceptor and then incubating the inoculated medium in anaerobic jars (Spring et al., 2001). The reduction of nitrate and the oxidation of thiosulfate were monitored by using an ion chromatograph (model 790 
personal IC; Metrohm) equipped with a conductivity detector and an anion-exchange column (Metrosep Anion Supp 4; Metrohm).

In our experiments, R. fulvus IAM $15025^{\mathrm{T}}$ and R. spathiphylli LMG $23181^{\mathrm{T}}$ were obtained from culture collection centres, but the type strain of the type species of the genus, R. lindaniclasticus LMG $18385^{\mathrm{T}}$ (the only known strain of this species), could not be included, as the strain no longer exists (Mergaert et al., 2002). All strains were cultivated identically and tested under the same conditions for comparative studies. For the analysis of fatty acids, the strains were cultivated in tryptic soy broth (Difco) at $30{ }^{\circ} \mathrm{C}$ for 4 days because of the slow growth of strain $\mathrm{LCS}^{\mathrm{T}}$.

The Gram reaction was performed as described by Gerhardt et al. (1994). Cell morphology and motility were observed under a phase-contrast microscope (Optiphot; Nikon) at $1000 \times$ magnification with cells grown for $1-$ 7 days on R2A agar. Oxidase activity was tested using $1 \%$ $(w / v)$ tetramethyl-p-phenylenediamine, and catalase activity was tested using $3 \% \mathrm{H}_{2} \mathrm{O}_{2}$. Growth was investigated at temperatures ranging from 5 to $45{ }^{\circ} \mathrm{C}$ (using increments of $5{ }^{\circ} \mathrm{C}$ ), at pH $4-10$ (using increments of $1 \mathrm{pH}$ unit) and in different salt concentrations $(1,2,3$ and $5 \% \mathrm{NaCl})$. Hydrolysis of casein and starch was tested on casein agar and starch (Difco). An $\mathrm{H}_{2} \mathrm{~S}$-production test was performed on triple-sugar-iron agar (BBL). Carbon-source-utilization tests and additional physiological tests were performed using API 20NE, API 32GN, API $50 \mathrm{CH}$ and API ZYM galleries according to the instructions of the manufacturer (bioMérieux).

Fatty acid methyl esters were prepared and analysed as described previously (Klatte et al., 1994) using the standard Microbial Identification System (MIDI) for automated GC analysis (Sasser, 1990; Kämpfer \& Kroppenstedt, 1996). Isoprenoid quinones were extracted and purified as described previously (Tindall, 1990) and dried preparations were dissolved in $200 \mu \mathrm{l}$ 2-propanol; 1-10 $\mu \mathrm{l}$ samples were separated by HPLC without further purification.

Extraction of genomic DNA, PCR-mediated amplification of the 16S rRNA gene and sequencing of the purified PCR product were carried out according to Rainey et al. (1996). The 16S rRNA gene sequence was aligned with published sequences retrieved from EMBL by using CLUSTAL_X (Thompson et al., 1997) and was edited using BioEdit (Hall, 1999). The phylogenetic tree was constructed on the basis of the neighbour-joining method (Saitou \& Nei, 1987); distances were estimated using the Kimura twoparameter model (Kimura, 1983) with MEGA version 3.1 (Kumar et al., 2004). The resultant neighbour-joining tree topology was evaluated by using bootstrap analysis (Felsenstein, 1985) based on 1000 resampled datasets. The DNA $\mathrm{G}+\mathrm{C}$ content was determined by HPLC after hydrolysis, as described by Tamaoka \& Komagata (1984), and non-methylated $\lambda$ DNA (Sigma) was used as a standard. DNA-DNA hybridization to determine genomic relatedness was performed fluorometrically by following the method of Ezaki et al. (1989) using DNA probes labelled with photobiotin (A1935; Sigma) and 96-well microdilution plates (Greiner Bio-One) at $50.8{ }^{\circ} \mathrm{C}$.

The effect of thiosulfate on the growth of strain $\mathrm{LCS}^{\mathrm{T}}$ in succinate/mineral medium was quantified by determining the cellular dry weight (Table 1). It is clear that the growth yield was dependent on the amount of added thiosulfate. The optimal thiosulfate concentration was $10 \mathrm{mM}$ and the increase in biomass yield was obtained with the optimal concentration of thiosulfate. This result was similar to that reported for Limnobacter thiooxidans $\mathrm{CS}-\mathrm{K}^{\mathrm{T}}{ }^{\mathrm{T}}$ (Spring et al., 2001). Increases in the sulfate concentration, coupled with decreasing thiosulfate concentration, were observed. The concentration of thiosulfate in the medium decreased from 10 to $2 \mathrm{mM}$ and the sulfate concentration reached $12 \mathrm{mM}$ at stationary phase.

Strain LCS2 $^{\mathrm{T}}$ formed visible colonies $(0.2-0.5 \mathrm{~mm}$ in diameter) on $\mathrm{R} 2 \mathrm{~A}$ agar at $30{ }^{\circ} \mathrm{C}$ within $48 \mathrm{~h}$. No growth was observed at $5{ }^{\circ} \mathrm{C}$ or at temperatures above $40{ }^{\circ} \mathrm{C}$ within 14 days. The colonies were yellowish, translucent and shiny with entire edges. The cells were Gram-negative, nonmotile, non-spore-forming rods $(0.6-0.8 \times 1.5-3.0 \mu \mathrm{m})$.

Analysis of the $16 \mathrm{~S}$ rRNA gene sequence of strain $\mathrm{LCS}^{2}$, consisting of $1482 \mathrm{nt}$, indicated its membership of the genus Rhodanobacter (Fig. 1), the intrageneric relatedness of which ranges from 96.0 to $98.5 \%$ among the type strains of species. Strain $\mathrm{LCS}^{\mathrm{T}}$ showed 97.4, 96.9 and $96.8 \%$ sequence similarity with respect to the type strains of $R$. fulvus, R. lindaniclasticus and R. spathiphylli, respectively.

When DNA-DNA hybridizations were performed between strain $\mathrm{LCS}^{\mathrm{T}}$ and $R$. fulvus IAM $15025^{\mathrm{T}}$, a DNA relatedness of $31 \%$ was revealed, confirming that $\mathrm{LCS} 2^{\mathrm{T}}$ represents a distinct genomic species (Stackebrandt \& Goebel, 1994; Wayne et al., 1987).

Strain LCS2 $2^{\mathrm{T}}$ differed significantly from the type strains of Rhodanobacter species in terms of the acid-production, carbon-source-utilization and substrate-hydrolysis profiles, and also with regard to nitrate reduction. The phenotypic

Table 1. Effect of the initial concentration of thiosulfate on growth of strain $\mathrm{LCS}^{\top}$

For each thiosulfate concentration, the mean \pm SD for dry cell weight is given. The maximum value is highlighted in bold. Maximum growth of strain $\mathrm{LCS}^{\mathrm{T}}$ was reached after cultivation with $10 \mathrm{mM}$ thiosulfate at $30{ }^{\circ} \mathrm{C}$ for $90 \mathrm{~h}$.

\begin{tabular}{|lc|}
\hline $\mathrm{Na}_{2} \mathrm{~S}_{2} \mathrm{O}_{\mathbf{3}}$ concentration $(\mathbf{m M})$ & Dry cell weight $\left(\mathbf{m g ~ l}^{\mathbf{- 1}}\right)$ \\
\hline 0 & $64.6 \pm 5$ \\
5 & $75.9 \pm 7$ \\
$\mathbf{1 0}$ & $\mathbf{1 0 3 . 9 \pm 1 0}$ \\
15 & $97.3 \pm 10$ \\
20 & $101.2 \pm 11$ \\
\hline
\end{tabular}




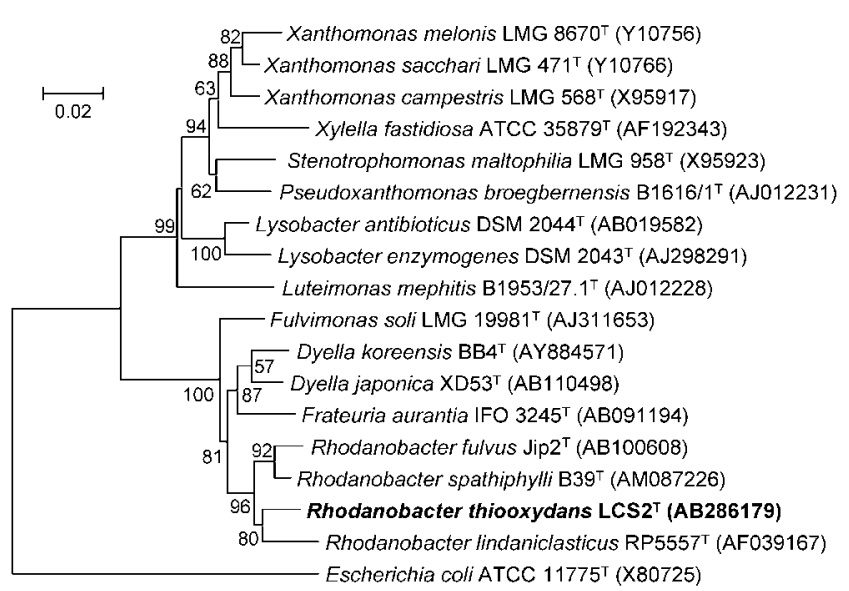

Fig. 1. Phylogenetic tree based on $16 \mathrm{~S}$ rRNA gene sequences, constructed using the neighbour-joining method (Saitou \& Nei, 1987), showing the position of strain $\operatorname{LCS}^{\top}$ among members of the family Xanthomonadaceae. Escherichia coli ATCC $11775^{\top}$ was used as an outgroup. Numbers at branching points refer to bootstrap percentages above $50 \%$ (based on 1000 resamplings). Bar, 2 substitutions per 100 nucleotide positions.

characteristics are summarized in Table 2 and the species description.

The major ubiquinone of strain $\operatorname{LCS} 2^{\mathrm{T}}$ was Q-8. The fatty acids $17: 1$ iso $\omega 9 c(22.0 \%), 15: 0(21.5 \%)$ and $17: 0$ iso (13.2\%) were predominant; the detailed fatty acid composition is shown in Table 3. Strain $\mathrm{LCS}^{\mathrm{T}}$ has a fatty acid profile similar to those of the type strains of Rhodanobacter species, but it has a larger proportion of $17: 1$ iso $\omega 9 c$ and a smaller proportion of $11: 0$ iso. Interestingly, the fatty acid profiles were rather different from those described by De Clercq et al. (2006) because of differences in the conditions employed. Strain $\mathrm{LCS}_{2}^{\mathrm{T}}$ and the two Rhodanobacter type strains were cultured under identical conditions, as mentioned above, for 4 days in order to secure sufficient quantities of fatty acids because of the slow growth of the novel strain.

On the basis of the phenotypic and genotypic data, strain LCS2 $^{\mathrm{T}}$ merits recognition as a novel species within the genus Rhodanobacter, for which the name Rhodanobacter thiooxydans sp. nov. is proposed.

\section{Description of Rhodanobacter thiooxydans sp. nov.}

Rhodanobacter thiooxydans (thi.o.ox'y.dans. Gr. n. thion sulfur; Gr. adj. oxus sharp, acid; N.L. v. oxydo to make acid, to oxidize; N.L. part. adj. thiooxydans oxidizing sulfur).

Cells are aerobic, non-motile, non-spore-forming rods $(0.6-0.8 \times 1.5-3.0 \mu \mathrm{m})$. Gram-negative and oxidase- and catalase-positive. Good growth is observed on R2A agar at 25-35 ${ }^{\circ} \mathrm{C}$ and $\mathrm{pH} 5-8$. Growth occurs in the presence of 1 and $2 \% \mathrm{NaCl}$. Colonies are yellowish, convex and circular
Table 2. Characteristics that differentiate strain $\mathrm{LCS}^{\top}{ }^{\top}$ from the type strains of Rhodanobacter species

Strains: $1, \mathrm{LCS}^{\mathrm{T}} ; 2$, R. fulvus IAM $15025^{\mathrm{T}} ; 3$, R. spathiphylli LMG $23181^{\mathrm{T}} ; 4$, R. lindaniclasticus LMG $18385^{\mathrm{T}}$. Data for $R$. lindaniclasticus were taken from Nalin et al. (1999). +, Positive; -, negative; ND, no data available.

\begin{tabular}{|c|c|c|c|c|}
\hline Characteristic & 1 & 2 & 3 & 4 \\
\hline $\mathrm{G}+\mathrm{C}$ content $(\mathrm{mol} \%)$ & 64.6 & 65.3 & 67.6 & 63.0 \\
\hline Motility & - & + & - & - \\
\hline Nitrate reduction & + & - & - & - \\
\hline Protease (gelatin) & + & - & - & ND \\
\hline \multicolumn{5}{|l|}{ Acid production from: } \\
\hline D-Xylose & - & + & - & ND \\
\hline Galactose & - & + & - & ND \\
\hline Glucose & - & + & - & $\mathrm{ND}$ \\
\hline Fructose & - & + & - & ND \\
\hline Mannose & - & + & - & ND \\
\hline Amygdalin & - & + & - & ND \\
\hline Salicin & - & + & - & $\mathrm{ND}$ \\
\hline Maltose & - & + & + & ND \\
\hline Lactose & - & + & - & $\mathrm{ND}$ \\
\hline Melibiose & - & + & - & ND \\
\hline Starch & - & + & - & ND \\
\hline \multicolumn{5}{|l|}{ Utilization of: } \\
\hline D-Mannose & - & + & - & - \\
\hline D-Melibiose & - & + & - & - \\
\hline D-Ribose & + & - & - & - \\
\hline Sucrose & - & + & - & - \\
\hline Glycogen & + & - & - & - \\
\hline Salicin & - & + & - & - \\
\hline Valerate & + & - & + & ND \\
\hline \multicolumn{5}{|l|}{ Hydrolysis of: ${ }^{*}$} \\
\hline 2-Naphthyl butyrate & + & - & - & ND \\
\hline 2-Naphthyl caprylate & - & + & + & ND \\
\hline $\begin{array}{l}\text { 6-Bromo-2-naphthyl } \alpha \text {-D- } \\
\text { galactopyranoside }\end{array}$ & - & + & - & ND \\
\hline $\begin{array}{l}\text { 1-Naphthyl } N \text {-acetyl- } \beta \text {-D- } \\
\text { glucosaminide }\end{array}$ & - & + & + & ND \\
\hline
\end{tabular}

${ }^{\star}$ Data from API ZYM tests. The intensity of the colour was measured on a scale from 0 to 5 and was interpreted as negative when values were 0 or 1 and positive when values ranged from 2 to 5 (Mudarris et al., 1994).

with entire edges. Uses carboxylic acids and amino acids as energy and carbon sources, but cannot grow autotrophically. Thiosulfate is oxidized to sulfate in the presence of an organic carbon source. Elemental sulfur is not deposited intracellularly or extracellularly during growth on media containing thiosulfate. $\beta$-Galactosidase activity is present. Nitrate is reduced, but nitrite is not. Indole and $\mathrm{H}_{2} \mathrm{~S}$ are not produced. Aesculin and gelatin are hydrolysed, but casein, starch and urea are not. Acid is produced from aesculin and D-fucose, but not from glycerol, erythritol, Darabinose, L-arabinose, ribose, D-xylose, L-xylose, adonitol, methyl $\beta$-D-xylose, galactose, glucose, fructose, mannose, 
Table 3. Cellular fatty acid profiles of strain $\operatorname{LCS}^{\top}$ and available type strains of the genus Rhodanobacter

Strains: 1 , LCS2 $2^{\mathrm{T}} ; 2$, R. fulvus IAM $15025^{\mathrm{T}} ; 3$, R. spathiphylli LMG $23181^{\mathrm{T}}$. Fatty acids are listed using standard abbreviations (no. of carbon atoms: no. double bonds). All strains were grown in tryptic soy broth at $30{ }^{\circ} \mathrm{C}$ for 4 days. -, Not detected.

\begin{tabular}{|lrrr|}
\hline Fatty acid & $\mathbf{1}$ & $\mathbf{2}$ & $\mathbf{3}$ \\
\hline $11: 0$ iso & 4.1 & 13.7 & 10.7 \\
Unknown (ECL & 2.7 & 4.1 & 3.5 \\
$11.798)^{*}$ & & & \\
$11: 0$ iso $3-\mathrm{OH}$ & 3.5 & 8.6 & 8.9 \\
$14: 0$ iso & 1.5 & 1.7 & 3.2 \\
$13: 0$ iso 3-OH & 2.9 & 10.6 & 6.8 \\
$15: 0$ iso & 21.5 & 24.4 & 22.8 \\
$15: 0$ anteiso & 8.3 & 4.9 & 5.3 \\
$16: 0$ iso & 6.5 & 5.7 & 8.2 \\
Summed feature $4 \dagger$ & 10.4 & 4.6 & 4.5 \\
$16: 0$ & 3.7 & 5.7 & 3.2 \\
$17: 1$ iso $\omega 9 c$ & 22.0 & 4.1 & 16.7 \\
$17: 0$ iso & 13.2 & 9.1 & 6.2 \\
$17: 0$ cyclo & - & 2.7 & - \\
& & & \\
\hline
\end{tabular}

${ }^{\star} \mathrm{ECL}$, Equivalent chain-length (i.e. the identity of the fatty acid is unknown).

$\dagger$ Summed feature 4 contains $15: 0$ iso $2-\mathrm{OH}$ and/or $16: 1 \omega 7 c / t$.

sorbose, rhamnose, dulcitol, inositol, mannitol, sorbitol, methyl $\alpha$-D-mannoside, methyl $\alpha$-D-glucoside, $N$-acetylglucosamine, amygdalin, arbutin, salicin, cellobiose, maltose, lactose, melibiose, sucrose, trehalose, inulin, melezitose, raffinose, starch, glycogen, xylitol, gentiobiose, D-turanose, D-lyxose, D-tagatose, L-fucose, D-arabitol, L-arabitol, gluconate, 2-ketogluconate or 5-ketogluconate. The following compounds are utilized as sole carbon sources: D-glucose, $\mathrm{N}$-acetyl-D-glucosamine, maltose, D-ribose, glycogen and valerate. The following carbon sources are not utilized: L-arabinose, mannose, gluconate, caprate, adipate, D-mannitol, citrate, phenylacetate, L-rhamnose, inositol, sucrose, itaconate, suberate, malonate, acetate, DL-lactate, L-alanine, 5-ketogluconate, 3-hydroxybenzoate, L-serine, salicin, D-melibiose, L-fucose, D-sorbitol, propionate, L-histidine, 2-ketogluconate, 3-hydroxybutyrate, 4-hydroxybenzoate and L-proline. 2-Naphthyl phosphate ( $\mathrm{pH}$ 8.5), 2-naphthyl butyrate, L-leucyl 2-naphthylamide, 2-naphthyl phosphate ( $\mathrm{pH}$ 5.4), naphthol-AS-BI-phosphate and 6-bromo-2naphthyl $\beta$-D-glucopyranoside are hydrolysed, but 2-naphthyl caprylate, 2-naphthyl myristate, L-valyl 2-naphthylamide, L-cystyl 2-naphthylamide, $\mathrm{N}$-benzoyl-DL-arginine 2-naphthylamide, $\mathrm{N}$-glutaryl-phenylalanine 2-naphthylamide, 6-bromo-2-naphthyl $\alpha$-D-galactopyranoside, 2naphthyl $\beta$-D-galactopyranoside, naphthol-AS-BI- $\beta$-Dglucuronide, 2 -naphthyl $\alpha$-D-glucopyranoside, 1-naphthyl $N$-acetyl- $\beta$-D-glucosaminide, 6-bromo-2-naphthyl $\alpha$-Dmannopyranoside and 2-naphthyl $\alpha$-L-fucopyranoside are not hydrolysed. The major quinone is ubiquinone Q-8. The predominant fatty acids are $17: 1$ iso $\omega 9 c(22.0 \%), 15: 0$ iso $(21.5 \%)$ and $17: 0$ iso $(13.2 \%)$. The $\mathrm{G}+\mathrm{C}$ content of the DNA of the type strain is $64.6 \mathrm{~mol} \%$.

The type strain, $\operatorname{LCS}_{2}^{\mathrm{T}}\left(=\mathrm{DSM} 18863^{\mathrm{T}}=\mathrm{KCTC} 12771^{\mathrm{T}}\right)$, was isolated from a biofilm of sulfur particles used in an autotrophic denitrification process.

\section{Acknowledgements}

This work was supported by the 21C Frontier Microbial Genomics and Applications Center Program, Ministry of Science and Technology (grant MG05-0101-4-0) of the Republic of Korea.

\section{References}

Batchelor, B. \& Lawrence, A. W. (1978). Autotrophic denitrification using elemental sulfur. J Water Pollut Control Fed 50, 1986-2001.

Claus, G. \& Kutzner, H. J. (1985). Autotrophic denitrification by Thiobacillus denitrificans in a packed bed reactor. Appl Microbiol Biotechnol 22, 289-296.

De Clercq, D., Van Trappen, S., Cleenwerck, I., Ceustermans, A., Swings, J., Coosemans, J. \& Ryckeboer, J. (2006). Rhodanobacter spathiphylli sp. nov., a gammaproteobacterium isolated from the roots of Spathiphyllum plants grown in a compost-amended potting mix. Int J Syst Evol Microbiol 56, 1755-1759.

Ezaki, T., Hashimoto, Y. \& Yabuuchi, E. (1989). Fluorometric deoxyribonucleic acid-deoxyribonucleic acid hybridization in microdilution wells as an alternative to membrane filter hybridization in which radioisotopes are used to determine genetic relatedness among bacterial strains. Int J Syst Bacteriol 39, 224-229.

Felsenstein, J. (1985). Confidence limits on phylogenies: an approach using the bootstrap. Evolution 39, 783-791.

Frankel, R. B., Bazylinski, D. A., Johnson, M. S. \& Taylor, B. L. (1997). Magneto-aerotaxis in marine coccoid bacteria. Biophys J 73, 994-1000.

Gerhardt, P., Murray, R. G. E., Wood, W. A. \& Krieg, N. R. (editors) (1994). Methods for General and Molecular Bacteriology. Washington, DC: American Society for Microbiology.

Hall, T. A. (1999). BioEdit: a user-friendly biological sequence alignment editor and analysis program for Windows 95/98/NT. Nucleic Acids Symp Ser 41, 95-98.

Im, W.-T., Lee, S.-T. \& Yokota, A. (2004). Rhodanobacter fulvus sp. nov., a $\beta$-galactosidase-producing gammaproteobacterium. J Gen Appl Microbiol 50, 143-147.

Kämpfer, P. \& Kroppenstedt, R. M. (1996). Numerical analysis of fatty acid patterns of coryneform bacteria and related taxa. Can J Microbiol 42, 989-1005.

Kimura, M. (1983). The Neutral Theory of Molecular Evolution. Cambridge: Cambridge University Press.

Klatte, S., Rainey, F. A. \& Kroppenstedt, R. M. (1994). Transfer of Rhodococcus aichiensis Tsukamura 1982 and Nocardia amarae Lechevalier and Lechevalier 1974 to the genus Gordona as Gordona aichiensis comb. nov. and Gordona amarae comb. nov. Int J Syst Bacteriol 44, 769-773.

Koenig, A. \& Liu, L. H. (1996). Autotrophic denitrification of landfill leachate using elemental sulphur. Water Sci Technol 34 (56), 469-476.

Kumar, S., Tamura, K. \& Nei, M. (2004). MEGA3: integrated software for molecular evolutionary genetics analysis and sequence alignment. Brief Bioinform 5, 150-163. 
Mergaert, J., Cnockaert, M. C. \& Swings, J. (2002). Fulvimonas soli gen. nov., sp. nov., a $\gamma$-proteobacterium isolated from soil after enrichment on acetylated starch plastic. Int J Syst Evol Microbiol 52, 1285-1289.

Mudarris, M., Austin, B., Segers, P., Vancanneyt, M., Hoste, B. \& Bernardet, J. F. (1994). Flavobacterium scophthalmum sp. nov., a pathogen of turbot (Scophthalmus maximus L.). Int J Syst Bacteriol 44, 447-453.

Nalin, R., Simonet, P., Vogel, T. M. \& Normand, P. (1999). Rhodanobacter lindaniclasticus gen. nov., sp. nov., a lindane-degrading bacterium. Int J Syst Bacteriol 49, 19-23.

Rainey, F. A., Ward-Rainey, N., Kroppenstedt, R. M. \& Stackebrandt, E. (1996). The genus Nocardiopsis represents a phylogenetically coherent taxon and a distinct actinomycete lineage: proposal of Nocardiopsaceae fam. nov. Int J Syst Bacteriol 46, 1088-1092.

Saitou, N. \& Nei, M. (1987). The neighbor-joining method: a new method for reconstructing phylogenetic trees. Mol Biol Evol 4, 406-425.

Sasser, M. (1990). Identification of bacteria by gas chromatography of cellular fatty acids, MIDI Technical Note 101. Newark, DE: MIDI Inc.

Spring, S., Kämpfer, P. \& Schleifer, K. H. (2001). Limnobacter thiooxidans gen. nov., sp. nov., a novel thiosulfate-oxidizing bacterium isolated from freshwater lake sediment. Int J Syst Evol Microbiol 51, 1463-1470.
Stackebrandt, E. \& Goebel, B. M. (1994). Taxonomic note: a place for DNA-DNA reassociation and $16 \mathrm{~S}$ rRNA sequence analysis in the present species definition in bacteriology. Int $J$ Syst Bacteriol 44, 846-849.

Tamaoka, J. \& Komagata, K. (1984). Determination of DNA base composition by reverse-phased high-performance liquid chromatography. FEMS Microbiol Lett 25, 125-128.

Thompson, J. D., Gibson, T. J., Plewniak, F., Jeanmougin, F. \& Higgins, D. G. (1997). The CLUSTAL_X windows interface: flexible strategies for multiple sequence alignment aided by quality analysis tools. Nucleic Acids Res 25, 4876-4882.

Tindall, B. J. (1990). A comparative study of the lipid composition of Halobacterium saccharovorum from various sources. Syst Appl Microbiol 13, 128-130.

Wayne, L. G., Brenner, D. J., Colwell, R. R., Grimont, P. A. D., Kandler, O., Krichevsky, M. I., Moore, L. H., Moore, W. E. C., Murray, R. G. E. \& other authors (1987). International Committee on Systematic Bacteriology. Report of the ad hoc committee on reconciliation of approaches to bacterial systematics. Int J Syst Bacteriol 37, 463-464.

Zhang, T. C. \& Lampe, D. G. (1999). Sulfur: limestone autotrophic denitrification processes for treatment of nitrate-contaminated water: batch experiments. Water Res 33, 599-608. 